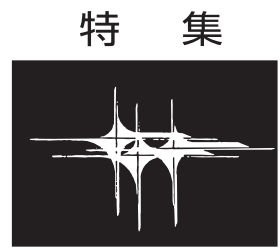

\title{
特集: 再生医療の産業化に向けて
}

\section{自動初代培養装置が開く再生医療}

久保寛 嗣*

\section{1.はじめに}

細胞シート工学はその技術が発明されて以 来 $^{1,2)}$, さまざまな細胞に対して適用され, 現 在では角膜を初めとする臨床レベルでの治療に 応用されるなど, 再生医療による医療の発展を 推し進める非常に強力な技術としての地位を確 立しつつある ${ }^{3)}$. 現在, 細胞シート製造工程は 医師，研究者などが熟練の技術を駆使し，さら に臨床で利用されるヒト細胞を使用した細胞シ 一ト製造であればCPC (Cell Processing Center）などのクリーン度，清潔度を高度に管 理された製造施設の中で目的の細胞シートを作 り出している. 今後, 細胞シート工学を利用し た再生医療が益々普及するにつれ, 現在の手作 業による細胞シート作製では製造が需要に対し て追いつかなくなり, 安定した細胞シート製造 を自動化するシステムが必要となってくること
は必須であると考えられる。

現在，われわれは東京女子医科大学岡野教授 を中心研究者とする最先端研究開発支援プログ ラム (以下，Firstプログラム $)^{4)}$ の組織ファク トリの開発グループに参画し，骨格筋組織から 移植に必要な積層化筋芽細胞シートを製造する 工程をモデルケースとして，骨格筋組織からの 筋芽細胞単離, 拡大培養, 細胞シート作製, 細 胞シート積層化までの工程を自動化する研究開 発プロジェクトを推進させている（図 1 )。自 動化に際しては，今まで培養技術者が持ってい た匠の技をいかに機械で代替させるかというこ とはもちろんであるが，機械による製造工程を 経て生産されてきた細胞が安心して使用できる 品質を有していることを客観的に示さなければ ならない．細胞の品質管理をどのように定量化 かつシステマチックにおこなっていくかが非常 に重要になる。

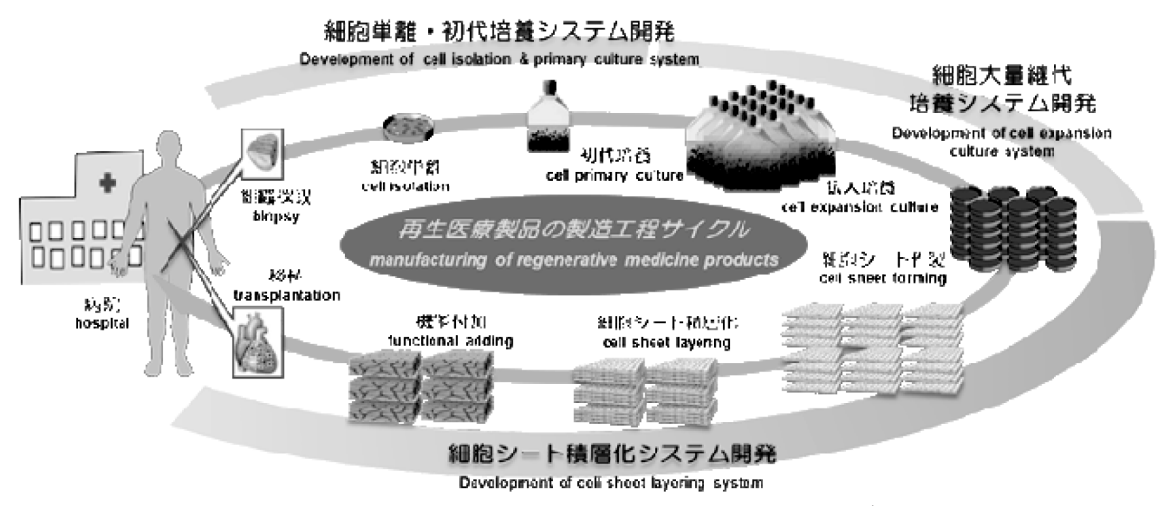

図1 組 織ファクトリ概念図 ${ }^{14)}$

* 日本光電工業株式会社 荻野記念研究所 河田町研究室 
手作業にて培養がおこなわれていた場合は, 培養実施者の顕微鏡での視覚的観察により，培 地の交換，継代夕イミングなどのケアを適切に おこない, 最終的な培養細胞の品質を維持して きた。この定性的な評価（ノウハウ）を基に培 養が接こなわれるため, 熟練の培養技術者と新 人の技術者での培養成績の差が激しく，それに より細胞の品質が大きく左右されてきた。機械 による自動培養ではその熟練技術者の目を持つ ことはできないため, 培養技術者の経験の裏に 隠れている技術を定量化し, それら定性的評価 に代替しうる新しい細胞の品質管理システムが 必要である。

本報では，本プロジェクトでの取り組みとし て, 細胞シート製造の初めの工程である細胞単 離・初代培養システムの構築と, 培養細胞の品 質管理を目的とした培養細胞の品質を一定に保 ち，かつ細胞が培養されてきた環境のトレーサビ リティを確保することのできる培養状態のモニ夕 リングシステムの研究開発について紹介する.

\section{2. 細胞シート工学による再生医療的 治療}

東京女子医科大学岡野教授らの開発した細胞 シート工学は培養狦上の表面温度を変化させる だけで，培養皿表面を親水性，疎水性を相互に 変化させることができ，その性質を利用して， 細胞の接着, 剥離を制御できることが大きな特 徵である。細胞を剥離する際, 酵素などを使用 せずに済むため, 細胞間結合構造をそのまま維 持してシート状に回収することができる ${ }^{5)}$.

現在，その技術を用いてさまざまな細胞が細 胞シートとして回収することに成功した例が報 告され ${ }^{6,7)}$, 従来の細胞懸濁液を直接疾患部位 注入法では細胞損失の問題で広く普及が進まな かった細胞治療法が注目されるようになってき た。これまでに動物細胞での前臨床的な臨床基 礎技術の確立を進め ${ }^{8 \sim 10)}$, 現在では, ヒト組織 由来の骨格筋, 角膜, 歯根膜, 食道粘膜などの 細胞シートを作製し, 疾患部位に移植する臨床 応用が進んできており ${ }^{11)}$, 細胞シートを用いた 治療は今後再生医療学的な細胞治療の大きな柱 になると予測される。

\section{3. 細胞シート製造の流れ}

細胞シート作製において，その製造工程は大 きくわけて次の 5 段階の工程にわけられる.す なわち, (1) 患者からの組織採取工程, (2) 細胞 単離・初代培養工程, (3) 細胞継代·大量増幅 培養工程, (4) 細胞シート作製・積層化工程, (5) 患者への移植である。ヒト臨床に用いる場 合は，現在は患者に対し細胞シート移植治療を おこなう計画を立て，医師がこの 5 工程のすべ てに関わり，個々の患者の治療計画に乗っ取り 移植のための細胞シート作製がなされ，最終的 に患者に移植されることになる。

しかし，今後このような再生医療学的治療法 が普及し, 細胞シートの需要が増大してくる と，現在のように製造工程のすべてに医師が関 わり，移植をおこなう医師すべてが細胞シート 製造の技術を習得しなければ，治療ができない 状態では，広く一般に浸透する治療法としては 不十分である，細胞シート製造は細胞培養を専 門におこなう別の組織体に任せ，医師は患者の 治療計画と組織採取，シート移植に集中できる 体制を作ることが必須である.

\section{4. 手作業での細胞シート作製から 自動化によるファクトリでの 大量・高品質生産へ}

現在，細胞培養をおこなう施設において通常 の細胞単離・初代培養工程をおこなう際には, 熟練の細胞培養技術者が細胞培養室にてクリー ンベンチ, 安全キャビネットなどの設備を利用 し培養をおこなっている．培養技術者は生物， 化学, 医療系の大学, 専門学校などの教育機関 にて無菌操作，培地交換法など細胞培養に必要 な基本的技術を習得するための教育訓練を受け て通常作業に従事している。細胞培養行為は培 養技術者の所作の節々に教科書には明文化され ていない熟練の技が隠れており，往々にしてそ の技を入れるか否かにより，培養細胞の品質に 多大な影響が現れるという側面を有していた。 細胞の増殖，活性度合いが培養する人に依存 する所以である。細胞シートの品質のばらつ きは, 安定した細胞シートを生産する上での 
大きな障害となり，人的工数の増大は製造コス トの上昇を招き，医療費の抑制が叫ばれる昨今 の医療社会事情に合致しない。

そこで求められるのは, 安心・安全・安価な 細胞シートを大量生産させる細胞シート自動シ ステムの開発である，この自動製造システムの 開発を成功させることが，医師単位によりおこ なわれている再生医療学的治療を産業として確 立し, 広く一般に普及させるための核となると 思われる。

前述した細胞シート製造工程のうち, 患者か らの組織採取と, 患者への細胞シート移植は医 師以外では関与できないため, 自動化の対象と なるのは組織を受け取ってからの細胞単離・初 代培養から細胞シート積層化までの工程であ る。医師が摘出した組織を自動製造システムに 投入するだけで, 移植用の積層化された細胞シ ートを製造するシステムを開発することができ れば，先に問題となっていた人的工数を大幅に 減らすことができ，さらに人的技術差による品 質のばらつきも抑えることができる.

これにより現在製薬と医療との間での分業体 制が確立している創薬と医療行為が, 再生医療 の分野でもシート製造と医療行為の分業体制を 確立することができ，再生医療的治療法の確立 に大きく寄与するものと思われる，さらに，開 発された細胞培養システムは安心・安全・安定 した細胞シート作製に大いに寄与し，再生医療 産業化に対する確実なステップアップとなる。

\section{5 . 細胞単離 - 初代培養工程}

現在，筆者らが開発を進めているのは自動 化工程の中の最初の工程である細胞単離・初 代培養工程の自動化である. 筋芽細胞シート 作製を例とした場合, 現在, 手作業での細胞単 離・初代培養工程は以下のような手順となる。 (1) 患者より骨格筋組織を採取する. (2) 組織か ら脂肪, 線維組織を取り除く（トリミング）. (3) コラゲナーゼなどの細胞間接着タンパクを 分解する酢素を用いることで細胞間の結合組織 を溶解し，組織から細胞を単離する。(4) 回収 した細胞を遠心分離，洗浄動作をおこない，細 胞懸濁液を得る。(5) 回収した細胞懸濁液を培
養皿上に播種する. (6) 播種後, コンフルエン 卜になるまで初代培養をおこなう。ただし，筋 芽細胞の場合は，コンフルエントになると，隣 接する筋芽細胞同士が細胞融合をおこし，多核 化した筋管を形成するため，分化を押さえるた めにサブコンフルエントになった状態で, 次工 程である継代・大量培養工程に受け渡される。

\section{1 ) 細胞単離}

筋芽細胞を取得するための骨格筋は, 筋原線 維とそれを覆う筋膜, 細胞間を埋める結合組織 から構成される。筋芽細胞は, 胎生期に筋芽細 胞から分化し，筋管形成を経て筋原線維とし て分化が終了するが，一部の筋芽細胞は分化 せず，そのまま筋衛星細胞として休止状態に 入る．成熟した筋原線維の周りには，この分化 を休止した状態の筋衛星細胞が存在し，これら は組織の損傷時などに休止より目覚め, 活性化 し筋芽細胞として分化を始め新たな筋原線維と して構築される．細胞単離処理はまさにこの眠 つている筋原線維中の筋衛星細胞 (筋芽細胞) を，コラゲナーゼ，トリプシンなどの細胞間接 着を溶解する処理を施すことにより，生きたま ま回収する操作である。この筋芽細胞をいかに 活きの良い状態で効率よく回収するかが重要な 技術開発要素となる。また，回収された細胞懸 濁液の中には, 線維芽細胞, 筋芽細胞が含まれ, 次工程での大量培養工程に受け渡しする時の境 界条件として，筋芽細胞の収率を上げることも 求められる。初代培養時には, 採取する組織の 性質により, 細胞の純度, 増殖度合, 細胞組成 が大きく左右される。この最初の細胞の性質の ばらつき, 特に筋芽細胞と線維芽細胞の含有比 率をある程度一定にすることは安定した細胞シ ートの品質を保つのに非常に重要である.今回 われわれが解決しなければならない大きな課題 の 1 つとして，この筋芽細胞, 線維芽細胞も構 成比率を制御する方法を確立することが挙げら れている。

本プロジェクトでは細胞単離システムの開発 をおこない，ターゲットを筋芽細胞にした細胞 単離技術を獲得するための検討をおこなった。

\section{2) 自動培養システム}

近年機械化, 省力化の波は細胞培養の世界に 
も波及しつつあり, 自動培養装置としては自動 継代培養装置や, 細胞破砕装置などいくつかの 自動化アイテムが近年世の中に出現しつつあ る.しかしながら, 組織からの細胞単離, 細胞 懸濁液作製までの一連の工程を自動化させた例 は世界でもあまり報告されていない。その理由 はいくつか考えられるが，主に考えられる原因 としては, 細胞種ごとに細胞単離する手法が異 なること, 最初の入力である組織の品質が患者 個人に大きく依存し, 一定の細胞数を得るため には培養期間，ミンスサイズの最適化など，細 かな調整が必要であるなど, さまざまな理由が 挙げられる。ささらに自動化実現のためには, 滅 菌処理した培地, 培養血, ピペットチップなど の培養機材の搬入を滅菌状態を維持したまま確 実に作業空間に搬入する方法を確立すること， 培養空間自体の滅菌方法を確立すること, でき 上がった細胞懸濁液の次工程への供出法を確立 することなどがあり，その個々に対して確実な 回答を用意しつつ開発作業を進めなければなら ない.

細胞単離・初代培養工程を自動化すること により，(1) 熟練の細胞培養技術者がいなく ても初代培養に必要な細胞が取得可能となり, (2) 培養工程に人の手が介在しないことによる コンタミリスクの低減することができる，さら に, (3) 培養作業に要する人的工数の大幅な削 滅を実現することができるなどのメリットがあ る.

今回, Firstプログラム内で筆者らの研究グ ループは, 細胞単離・初代培養工程自動化のた めの機能試作機を開発した (図 2 ). 本システ ムは, 細胞単離装置を中心として, 人の手作業
をなるべく忠実に再現させることのできる 6 軸 のロボットアームを採用し, 遠枕管, ピペット チップ, 細胞単離用の容器, 培養孟をチャック の交換なしに把持，搬送できるハンドチャック を独自開発した。これらを用いることで，人間 の手の動きを再現しアームを中心として，遠心 分離, 培地, 洗浄液などの試薬供給モジュール, 細胞懸濁液作製のための懸濁モジュール，そし て外部に出すための遠沈管をキャップするため のキャッパユニットの配置をおこない, 細胞単 離, 遠心分離, 細胞洗浄, 細胞懸濁の各工程を 有機的につなげることのできる自動細胞単離・ 初代培養システムを開発した。本装置を用い, まずラット，豚の動物組織を用い，筋芽細胞の 培養試験をおこなったところ, 大腿部骨格筋組 織より筋芽細胞を生きたまま回収し, 初代培養 をおこなうことに成功した。

\section{6. 品質管理のためのモニタリング システム}

通常, 細胞培養をおこなう作業者は細胞懸濁 液播種の後, 細胞がコンフルエントに到達する まで，毎日観察をおこない，細胞の様子を確認 し, 必要に応じて培地交換をおこなう。培養状 態を把握する判断材料となるのは培養期間中に おいては顕微鏡観察などの視覚的な情報を主と し，培養技術者の熟練した経験によりその増 殖・活性度合いを判断している。ささらに, より 詳細な細胞培養状態を把握しょうとすると， サンプリング用の培養血を用意し, 固定後蛍光 抗体などで標識した細胞を観察することで目的 の機能を発現しているか否かを判定しているの が実情である. 紀ノ岡らの研究グループは連続
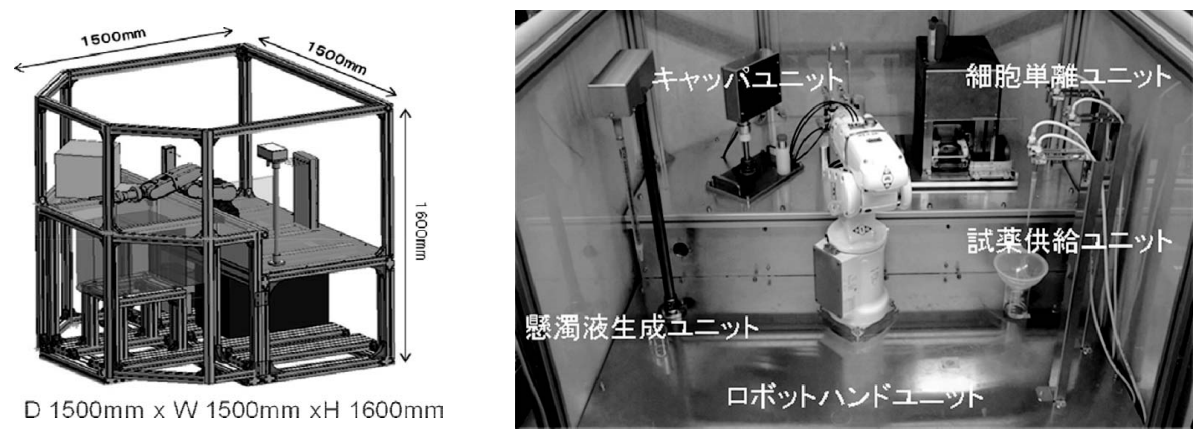

図 2 細胞単離・初代培養システム機能試作機 
的な培養中の細胞増殖過程を詳細に把握する ためにさまざまな培地成分分析をおこない ${ }^{12)}$, 培養中の細胞挙動の定量化をおこなっている. 本プロジェクトでも同様に, 初代培養にて回収 した細胞をそのまま細胞シート作製のための 細胞として次工程に渡す必要があるため, サ ンプリングによるロス，コンタミリスクを回避 しつつ, 細胞の増殖および分化度合いを生かし たまま評価・判断する指標を獲得することが必 要となる。また, 筋芽細胞に於いてはコンフ ルエントになり，隣接し合う細胞が接触しだ すと, 筋芽細胞は増殖を止め, 細胞融合を起 こし, 多核化した筋管形成を起こす。次工程に 渡すためには筋管形成を起こす前の筋芽細胞の 状態で受け渡さねばならないため，このコンフ ルエントに到達するまでの時間を注意深く観察 する必要がある。現在は，顕微鏡観察により， サブコンフルエント状態で継代培養をおこな い，細胞間の距離を離す工程をおこなっている が, 無菌が維持された自動化装置の庫内空間中 では安易に観察のために培養血を外部に出すこ とはできない.

特に組織から目的の細胞を単離してくる初代 培養工程においては, 単離時の酵素処理や組織 ミンス処理時の物理的な力により, 細胞がダメ ージを受けた状態にある。人間でいえば患者が 手術直後の ICUにいる時期に相当する。この 際に, その細胞が今どのような状態にあるのか, 細胞の代謝の状態, 培地の状態を常に監視し, なにか不測の事態が起きれば即アラームを鳴ら し，いち早く管理者に知らせることのできる培 養状態モニタリングシステムを構築すること
は, 高品質で安定した細胞シートを生産する上 で不可欠である。

さらに本プロジェクトが目指す, 安心・安 全・安価な自動細胞シート製造装置では, 元と なる細胞がどのような状態で取得され，どのよ うな条件で培養期間をすごし，移植の直前まで どのような状態が保たれていることを記録とし て残し，品質を保証する必要がある。実際に患 者の治療に使用しょうと意図して作製した細胞 シートの品質が不明のままでは移植術者も患者 も培養者も安心して手術を揬こなうことは不可 能であることは自明である。

\section{1 ) 非侵襲モニタリングシステム}

今回, Firstプロジェクトにて細胞の代謝の 状態を非侵襲で計測するモデルとして，図 3 の ような培養状態モニタリングシステムを開発す る。本システムは培養状態を 24 時間連続的に 監視し, 計測パラメータに不測の事態が発生 した場合，即管理者に通知が届く仕組みを備 える。これにより，従来の顕微鏡観察による 視覚情報に加え, 細胞の代謝, 活性, 増殖度合 いを把握することのできる指標としてのモニタ リングパラメータを確立し, 細胞治療を基軸と した再生医療においてもトレーサビリティのと れた品質保証システムを構築し, 安定した品質 の細胞シートを生み出す生産システムを構築す る.

一例として，光学的なアプローチによる非接 触型の $\mathrm{pH}$ 計測システムを開発した（図 4$)$. 細胞培養においては培養期間中の $\mathrm{pH}$ の管理は 最も大切な指標の 1 つであるが, 連続, かつ非 侵襲培養溶液中に含まれるフェノールレッドの

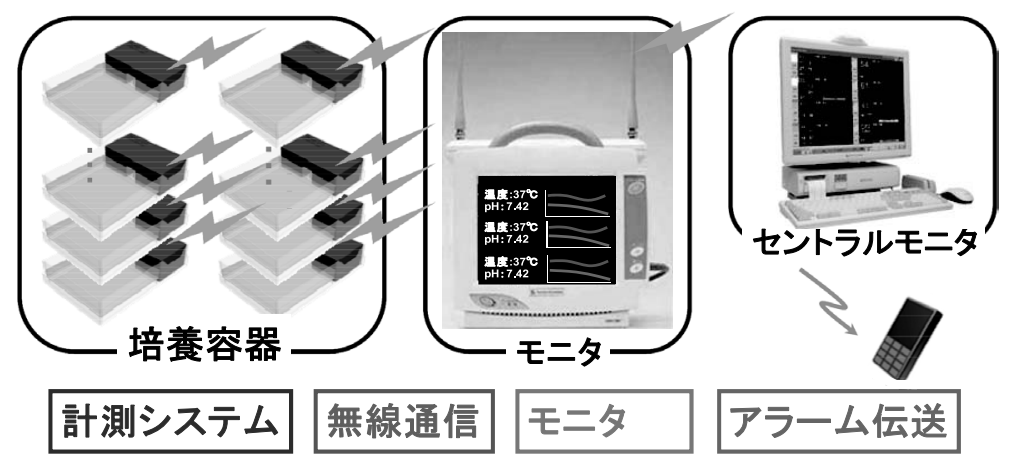

図3培養モニタリングシステム 

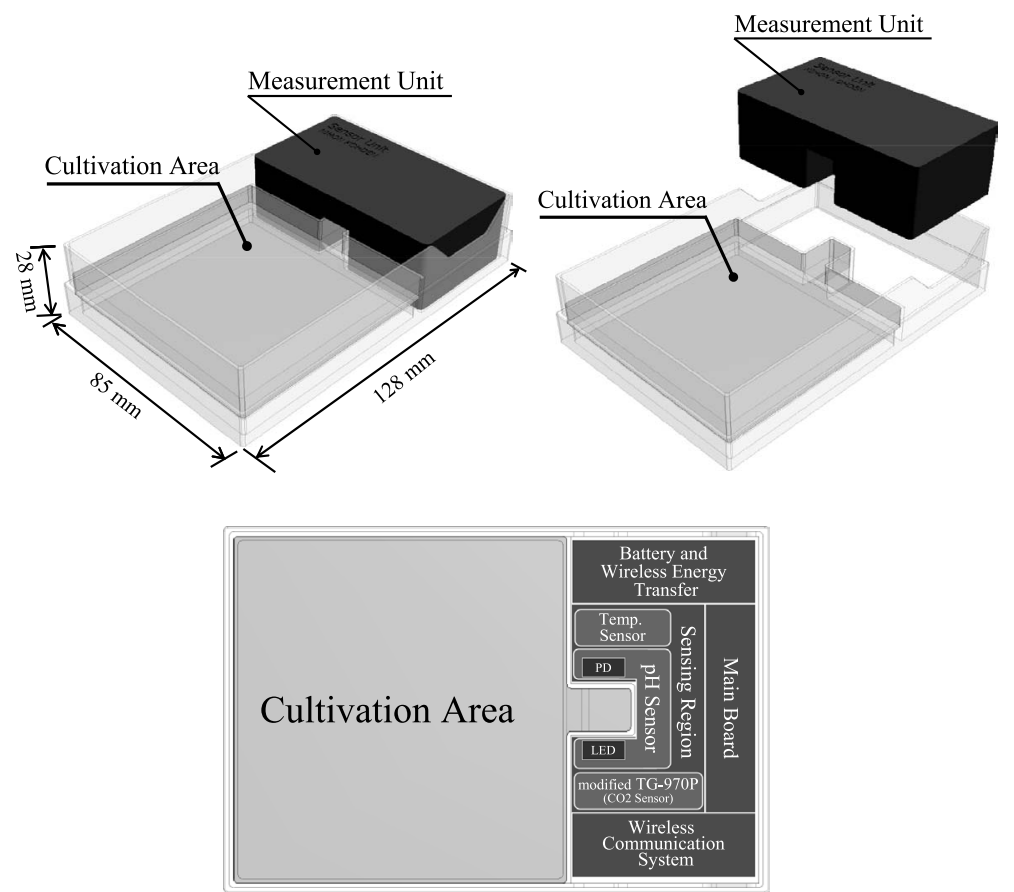

図 4 着脱式非接触 $\mathrm{pH}$ 計測ユニットと専用培養容器

吸光度を計測することで, 従来の電極法による 接触型の $\mathrm{pH}$ 測定装置と同等の性能を非接触に て計測することに成功した ${ }^{13)}$ 。本システムでは 培地中に含まれるフェノールレッドの吸光度の 変化量により培養中の $\mathrm{pH}$ の変化量を計測する ことができ，同時に連続的温度計測，ID 管理 をおこなうことができ，今後，グルコース， $\mathrm{pO}_{2}$, 乳酸, アンモニアなどの細胞代謝による 産生物質を計測することができれば，培養期間 中の細胞の状態を詳細に把握することが可能と なる。

\section{7.おわりに}

細胞シート工学の発展により, 従来の薬を使 用した治療行為と同様に細胞そのものを治療デ バイスとして利用することができる世界が現実 のものとなりつつある. 今後, 広く普及が進み, 再生医療的な治療が身近なものとなるとき, 細 胞シートの需要は一気に増大し, 安定した品質 の細胞シートを大量に生産しなければならない 時期がそう遠くない将来に訪れるであろう。そ の時までに, 現在の培養技術者の職人芸に頼っ た細胞培養技術を吸収し，発展させ，大量，高
品質，安定生産できる細胞シート製造ファクト リを創生し，新しい産業として育成しておかな ければならない。

\section{謝 辞}

本報をまとめるにあたり，多大なご指導を頂 きました岡野光夫教授，清水達也教授（東京女 子医科大学), 紀ノ岡正博教授 (大阪大学), 研 究推進時に多くの有益なコメントを頂きました 水谷学様, 田中理枝様（独立行政法人科学技術 振興機構FIRST 岡野プロジェクト支援室）に 厚く御礼申し上げます。

本研究は，総合科学技術会議により制度設計 された最先端研究開発支援プログラムにより， 日本学術振興会を通して助成されたものです。

\section{文献}

1 ) Yamada, N.; Okano, T.; Sakai, H. et al. Thermoresponsive polymeric surfaces; control of attachment and detachment of cultured cells. Makromol Chem Rapid Commun. 1990, 11, p. $571-576$.

2 ) Okano, T.; Yamada, N.; Okuhara. et al. 
Mechanism of cell detachment from temperature-modulated, hydrophilic-hydrophobic polymer surfaces. Biomaterials. 1995, 16, p. 297-303.

3 ) Nishida, K.; Yamato, M.; Hayashida, Y. et al. Corneal reconstruction with tissue-engineered cell sheets composed of autologous oral mucosal epithelium. The New England journal of medicine. 2004, 351, p. 1,187-1,196.

4 ）最先端研究開発支援プログラムー再生医療産 業化に向けたシステムインテグレーション. http://twins.twmu.ac.jp/first/index.html

5 ) Kikuchi, A.; Okuhara. M.; Karikusa. F. et al. Two-dimensional manipulation of confluently cultured vascular endothelial cells using temperature-responsive poly (N-isopropylacrylamide) -grafted surfaces. Journal of Biomaterials Science, Polymer Edition. 1998, Vol. 9 , No. 12, p. 1,331-1,348.

6 ) Shimizu, T.; Yamato, M.; Kikuchi, A. et al. Two-dimensional manipulation of cardiac myocyte sheets utilizing temperature-responsive culture dishes augments the pulsatile amplitude. Tissue Engineering. 2001, 7, p. 141151.

7 ) Kanzaki, M.; Yamato, M.; Hatakeyama, H. et al. Tissue engineered epithelial cell sheets for the creation of a bioartificial trachea. Tissue engineering. 2006, 12, p. 1,275-1,283.

8 ) Ohki, T.; Yamato, M.; Murakami, D. et al. Treatment of oesophageal ulcerations using endoscopic transplantation of tissue-engineered autologous oral mucosal epithelial cell sheets in a canine model. Gut. 2006, Dec, Vol.
55, No. 12, p. 1,704-1,710. Epub. 2006, May, 18.

9 ) Memon, I.A.; Sawa, Y.; Fukushima, N. et al. Repair of impaired myocardium by means of implantation of engineered autologous myoblast sheets. The Journal of thoracic and cardiovascular surgery. 2005, 130, p. 1,3331,341 .

10) Nishida, K.; Yamato, M.; Hayashida, Y. et al. Functional bioengineered corneal epithelial sheet grafts from corneal stem cells expanded ex vivo on a temperature-responsive cell culture surface. Transplantation. 2004, Feb, 15, Vol. 77, No. 3 , p. 379-385.

11) Ohki, T.; Yamamoto, M.; Ota. et al. Application of cell sheet technology for esophageal endoscopic submucosal dissection. Tech Gastrointest Endosc. 2011, Vol. 13, No. 1 , p. 105-109.

12) Medical Innovation of 21st Century "Challenge for the State of the Art Medical System Driven by Nanobiotechnology. 抄録集. Development of a New Cell Isolation System from Tissue for Regenerative Medicine. Shioyama, T.; Kubo, H.; Takeda, S. et al.

13）紀岡正博, 田谷正仁, “第24章 培地成分測定に 基づく細胞培養モニタリング”, “細胞培養 ・ 再生医療のための培養システム”. シーエムシ 一出版, 東京, 2010, 1 , 28, p. 214-224.

14) M. Oura.; H. Kubo.; T. Okano. et al. Development of Cell Culture Monitoring System and Novel Non-Contact pH Measurement. IEEE EMBS, Vol. 2 , No. 6 , P. 22-25.

15）組織ファクトリープロジェクト概要. http://twins.twmu.ac.jp/first/soshiki.html 